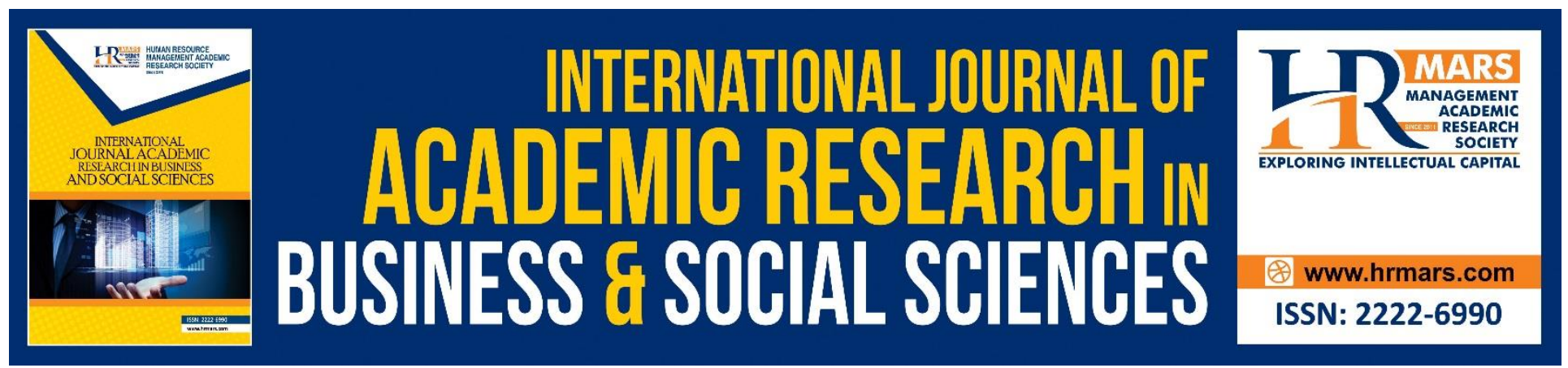

\title{
F\&B: Comparison Factor between Local and International Franchise towards Customer Preference
}

\section{Yuhanis binti Mohamed Noor}

To Link this Article: http://dx.doi.org/10.6007/IJARBSS/v8-i6/4304

DOI: $\quad 10.6007 /$ IJARBSS/v8-i6/4304

Received: 20 May 2018, Revised: 19 June 2018, Accepted: 24 June 2018

Published Online: 09 July 2018

In-Text Citation: (Noor, 2018)

To Cite this Article: Noor, Y. binti M. (2018). F\&B: Comparison Factor between Local and International Franchise towards Customer Preference. International Journal of Academic Research in Business and Social Sciences, 8(6), 1098-1109.

\section{Copyright: (C) 2018 The Author(s)}

Published by Human Resource Management Academic Research Society (www.hrmars.com)

This article is published under the Creative Commons Attribution (CC BY 4.0) license. Anyone may reproduce, distribute, translate and create derivative works of this article (for both commercial and non-commercial purposes), subject to full attribution to the original publication and authors. The full terms of this license may be seen

at: http://creativecommons.org/licences/by/4.0/legalcode

Vol. 8, No. 6, June 2018, Pg. 1098 - 1109

Full Terms \& Conditions of access and use can be found at http://hrmars.com/index.php/pages/detail/publication-ethics 


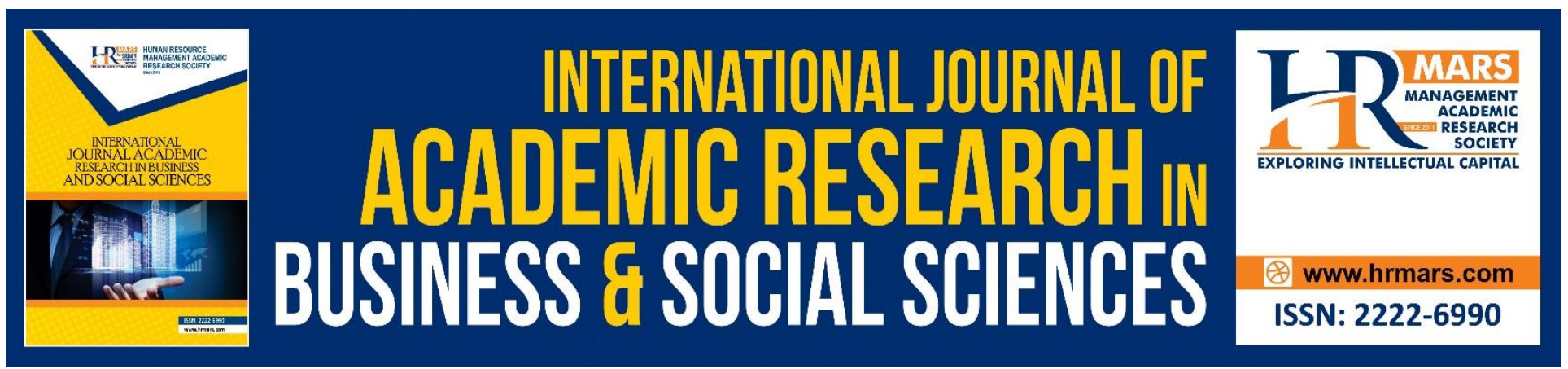

\title{
F\&B: Comparison Factor between Local and International Franchise towards Customer Preference
}

\author{
Yuhanis binti Mohamed Noor \\ Faculty of Entrepreneurship and Business, Universiti Malaysia Kelantan, Malaysia \\ Email: yuhanis.mn@umk.edu.my
}

\begin{abstract}
The franchise industry in Malaysia provided many incomes towards country's gross domestic products (GDP). In 2016, food and beverage (F\&B) industry are the most popular in Malaysia such as Cool Blog and Secret Recipe. In order to sustain market share in F\&B industry, franchisee prefers to buy licenses from food and beverage franchise which result in increased competitive challenges in this industry. Therefore, this study is to identify most influential factors towards customer preference towards local and international food and beverage in Malaysia as well as to compare the factors influence customer preference towards local and international food and beverage in Malaysia. This study was carried out by quantitative research and 384 target respondents been selected. Based on the finding, brand influence is the most influential factors for customer preference towards local and international F\&B franchise in Malaysia. Besides, three independent variables which are a brand influence, product quality, and service quality are significant that influence customer preference towards local and international F\&B franchise in Malaysia.
\end{abstract}

Keywords: Brand Influence, Food and Beverage Franchise Product Quality, Service Quality

\section{Introduction}

The franchise industry contributed 9.4 percent of country's gross domestic products (GDP) by 2020 from 2.0 percent in 2010 at Malaysia. This is happened since Malaysia Government provided four strategic thrusts that have been identified in the National Franchise Development Blueprint (NFDB) for 2012 to 2016. In result, the franchise industry in Malaysia has generated total revenue of RM 25.6 billion in 2015 that contributed by more than 400 local franchise companies. Those data showed that the income of the country can be increased from the contribution of the successful franchise company. F\&B industry conquered more than 31 percent of franchise market share which consist of franchise namely Cool Blog, Secret Recipe and Starbucks.

Starbucks is one of the great examples of an international franchise that being successful in running a business in Malaysia. Typically, Starbucks in Malaysia is operated by the Berjaya Starbucks Coffee Company Sdn. Bhd. which is a licensee of Starbucks Coffee International. Indeed, most of Malaysian especially young adults love to drink coffee and hang out at their favourite place like Starbucks. 
INTERNATIONAL JOURNAL OF ACADEMIC RESEARCH IN BUSINESS AND SOCIAL SCIENCES Vol. 8, No. 6, June 2018, E-ISSN: 2222-6990 @ 2018 HRMARS

The current trend in Malaysia showed that the unique F\&B franchise concept have very high demand among communities. This can support by the review from Habib, Abu Dardak, and Zakaria (2011) appended that F\&B industry in Malaysia conquers around 32 percent of the market share and it has a great potential to grow in future. Thus, it resulted F\&B industry in Malaysia are facing with fierce competition with same as other industries around the world (Ryan, Ghazali, \& Mohsin, 2011). In result, franchisee prefers to buy licenses from $F \& B$ franchise in order to penetrate the market at a recent year which results in increasing competitors in this sector. Indeed, Malaysian customers' taste and preference towards foods and beverages are rapidly changed that required $F \& B$ franchise with fierce marketing strategy in order to attract and retaining the customers. Therefore, this study is to identify most influential factors towards customer preference towards local and international food and beverage in Malaysia as well as to compare the factors influence customer preference towards local and international food and beverage in Malaysia.

\section{Literature Review}

\section{Customer Preference towards Food and Beverage}

Based on Sowunmi, Omigie, and Daniel (2014), customer preference can be known as personal taste which is evaluated by the value of the various bundle of services and goods. This indicated that companies must acknowledge the importance of customer preference since it is playing an important role in offering products and services in the market. Indeed, customers tend to purchase the goods based on their taste or fulfil their desire hence follow the purchasing power. Moreover, preference can be judgmental psychology terms in the feeling of like or dislike an object (Javalgi, Radulovich, Pendleton, \& Scherer, 2005). This is due to individuals that probably may dislike or not interested with products or services offered that leads to limited purchasing power. This is supported by the review from Fife-Schaw et al. (2007) stated that customer preference defined as "tending to indicate choices among various of liking to disliking options with acceptance reflecting a willingness to abide the status quo or less desirable option".

Indeed, the younger generation in Malaysia or people with higher purchasing power tend to prefer towards eating out by searching variety food since it can be a great motivator for eating outside of the home (de Rezende \& de Avelar, 2012). Therefore, customer preference towards food and beverage franchise can be evaluated by different intention. According to Richardson and Aguiar (2003), various factors include cleanliness, taste, convenience, speed and stability can influence main attributes for customers towards food and beverage franchise. Richardson and Aguiar (2003) added others factors include healthiness, friendly staff and relevant choice can be an influential factor as well.

Recently, most F\&B franchise build a strong brand image in order to cater the customers' taste and result to attract loyal customers. This can be supported by the review from lyer and Kuksov (2012) and Demirgünes (2014) stated store image plays an influential factor to affect customer's quality expectation of products quality since customers are related with store image towards product or service categories in F\&B franchise. Indeed, customer preference towards the goods not always influenced by the desire but based on actuality as well.

\section{Brand Influence}

Brand considered as second vital assets for the company after customers (Dib \& Alhaddad, 2014) since brand plays a very vital role to increase the income and economy of the country. Malki (2015) defined brand influence is a circle of customers belief towards the brand. Indeed, customers 
INTERNATIONAL JOURNAL OF ACADEMIC RESEARCH IN BUSINESS AND SOCIAL SCIENCES

Vol. 8, No. 6, June 2018, E-ISSN: 2222-6990 @ 2018 HRMARS

in Malaysia are aware of brand influence when making a decision on which F\&B product that they want to consume. Indeed, F\&B companies have the high concern to monitor their brand in order to sustain the market share since brand is able to help customers to recognize and differentiate the products (Zhang, 2015).

In result, a brand can be an influential factor towards customers' purchasing decision since the loyalty level of customers towards specific brands (Wahid \& Ahmed, 2011). Besides, a brand can be a factor for customers willing to pay a high price for that product (Chinomona, Mahlangu, \& Pooe, 2013). Indeed, the brand becomes the major factor for a company to increase current market share, especially in F\&B industry. Therefore, the hypothesis proposed as:

$H_{1}$ : There is a relationship between brand influence and customers preference towards local and international food and beverage franchise.

\section{Product Quality}

There are several explanations for product quality and one of the explanations from Buntak, Adelsberger, and Nađ (2012) stated that the products that can be comply with customers' requirement can be define as quality. Indeed, the researcher justifies the product quality can be achieved if the products meet the criteria of customers. This can be supported by the statement from Jahanshahi, Gashti, Mirdamadi, Nawaser, and Khaksar (2011) who stated that "if a product fulfils the customer's expectations, the customer will be pleased and consider that the product is of acceptable or even high quality". Besides, this statement also can be supported by the review from Suchánek, Richter, and Králová (2014) stated that "quality as the producer's ability to meet expectations". This indicated that perceived quality is the basis for customers to make the decision to evaluate excellence of a product based on the point of view.

Indeed, F\&B franchise need to provide products in great aesthetics especially in five-sense since aesthetics are one of the dimensions of product quality (Halim, 2014). Therefore, the researchers proposed the hypothesis as below:

$\mathrm{H}_{2}$ : There is a relationship between product quality and customers preference towards local and international food and beverage franchise.

\section{Service Quality}

The main objectives of every business are to maximize customers' satisfaction (Bhargava \& Pareek, 2013). Indeed, the company should concern on their service quality in order to increase customer satisfaction level. Moreover, the F\&B industry are similar with other departments that realize the significance of customer-centred philosophies and turning to quality management approaches to help managing their businesses. According to An and Noh (2009), the predominant method as a measurement of customers' perception towards service quality for international F\&B companies. Besides, it can measured by several factors include tangible, reliability, responsiveness, assurance and empathy (An \& Noh, 2009).

Therefore, each organization including F\&B industry must not avoid the elements of service quality that required enhancement from time to time in order to maintain current market or to create a new market. This can be supported by the review from Kamaruddin and Jusoff (2009) stated that the F\&B industry is one of the vital sectors in manufacturing industry in Malaysia. The hypothesis proposed below:

$H_{3}$ : There is a relationship between service quality and customers preference towards local and international food and beverage franchise. 
INTERNATIONAL JOURNAL OF ACADEMIC RESEARCH IN BUSINESS AND SOCIAL SCIENCES

Vol. 8, No. 6, June 2018, E-ISSN: 2222-6990 @ 2018 HRMARS

\section{Methodology}

This study is carried out by quantitative research and 380 target respondents who have tried or not either the local or international F\&B franchise at Malaysia were selected in this study. Besides, this study covered five regions at Malaysia which are the central, northern, southern, east, and east coast. Therefore, the researchers are using non-probability sampling techniques which is snowball sampling to select target respondents.

The research instrument in this study was a questionnaire. All items in the questionnaire are designed in straightforward in order to prevent confusion for target respondents. Besides, the questionnaires are being prepared in two languages which are Malay and English. There are five parts in this questionnaire: Part $A$ is to identify the feedback of target respondents towards customers' preference of local or international food and beverage franchise; Part B is to identify the feedback of target respondents towards brand influence of local or international food and beverage franchise; Part $C$ is to identify the feedback of target respondents towards product quality of local or international food and beverage franchise; Part $D$ is to identify the feedback of target respondents towards service quality of local or international food and beverage franchise; and Part $E$ is to identify the demographic profile of target respondents. All items in Part A, B, C, and D are designed in fivepoint Likert scale while Part D designed in nominal scale.

All data collected was analyse by SPSS version 22.0 and four data analysis methods are used which are reliability test, frequency analysis, Multiple Regression Analysis, and Comparative Regression. Each data analysis methods will be further discussion in next paragraph.

Reliability test is to identify the stability of questionnaire that can be supported for this study. Indeed, this test can identify the internal consistency of questionnaire for this study by measurement of Cronbach Alpha value. The researchers selected 30 target respondents in order to carry out this study. Based on Hair, Hult, Ringle, and Sarstedt (2016), the Cronbach Alpha value for all indicators must exceed 0.7 as consistency for this study.

Frequency analysis is to summarize demographic profile of target respondents in this study. Therefore, the researchers used frequency analysis to summary demographic profile for target respondents into frequency and percentage as well as illustrated in table form. Based on Hair et al. (2016), frequency analysis is capable for the researchers to transform data into useful information.

Multiple Regression Analysis that carry out by the researchers is to identify the correlation between all independent variables towards dependent variable in this study. Besides, this study capable to help the researchers to identify the most influential factors towards local and international food and beverage franchise. Moreover, the researchers carried out paired sample t-test to compare the factors of customers' preference towards local and international F\&B franchise by identifying $p$ value.

\section{Data Findings \\ Reliability Test}

The test is conducted in order to identify whether target respondents capable to understand all items in each indicator. The Cronbach Alpha values can be a measurement of the level of understanding among target respondents in this study. Table 1 showed that value of Cronbach Alpha is between 0.813 to 0.930 which indicated that all indicators are reliable due to exceeding 0.7 as per recommended value. 
INTERNATIONAL JOURNAL OF ACADEMIC RESEARCH IN BUSINESS AND SOCIAL SCIENCES Vol. 8, No. 6, June 2018, E-ISSN: 2222-6990 C 2018 HRMARS

Table 1. Reliability Analysis

\begin{tabular}{ccc}
\hline Factors & Number of items & Cronbach's Alpha \\
\hline Customer Preference & 6 & 0.813 \\
Brand Influence & 7 & 0.930 \\
Product Quality & 5 & 0.913 \\
Service Quality & 6 & 0.924 \\
\hline
\end{tabular}

\section{Respondents Demographic Characteristics}

Table 2 showed the summary of respondents' demographic characteristics for this research that showed below:

Table 2. Respondent's Demographic Characteristics

\begin{tabular}{lcc}
\hline \multicolumn{1}{c}{ Demographic } & Frequency & Percentage \\
\hline Gender & & \\
Male & 186 & 48.4 \\
Female & 198 & 51.6 \\
\hline Age & & \\
$18-29$ & 124 & 32.3 \\
$30-39$ & 155 & 29.9 \\
$40-49$ & 98 & 25.5 \\
$50-59$ & 47 & 12.2 \\
\hline Marital Status & & \\
Single & 233 & 60.7 \\
Married & 108 & 39.3 \\
\hline
\end{tabular}

Table 2. Respondent's Demographic Characteristics (Continued)

\begin{tabular}{lcc}
\hline \multicolumn{1}{c}{ Demograhpic } & Frequency & Percentage \\
\hline Race & 156 & 40.7 \\
Malay & 91 & 23.7 \\
Chinese & 72 & 18.8 \\
Indian & 65 & 16.9 \\
Others & & \\
Education & 66 & 17.2 \\
SPM & 93 & 24.2 \\
Diploma & 143 & 37.2 \\
Degree & 58 & 15.1 \\
Master & 24 & 6.3 \\
PhD & & \\
\hline Occupation & 122 & 31.8 \\
Student & 48 & 12.5 \\
Self-Employed & 93 & 24.4 \\
Government Sector & 121 & 31.5 \\
Private Sector & & \\
Income & 120 & 31.3 \\
Rm 2000 and Below & & \\
\hline
\end{tabular}


INTERNATIONAL JOURNAL OF ACADEMIC RESEARCH IN BUSINESS AND SOCIAL SCIENCES Vol. 8, No. 6, June 2018, E-ISSN: 2222-6990 @ 2018 HRMARS

\begin{tabular}{lcc}
\hline RM 2001- RM 5000 & 143 & 37.2 \\
RM 5001- RM 10000 & 87 & 22.7 \\
RM 10001 and Above & 34 & 8.9 \\
\hline Origin & & \\
Northern Region & 96 & 24.7 \\
Central Region & 131 & 34.1 \\
Southern Region & 52 & 13.5 \\
East Coast & 59 & 15.4 \\
Sabah and Sarawak & 47 & 12.2 \\
\hline
\end{tabular}

Based on the table above, majority respondents are female with a total number of 198 or $51.6 \%$. For the age of respondents, the majority are aged between 18 until 29 years old with $32.3 \%$ following by aged between 30 until 39 years old with $29.9 \%$. Moreover, most respondents are Malay with $40.6 \%$, followed by Chinese with $23.7 \%$. Furthermore, the majority are single in terms of marital status and a Degree holder in terms of education level. Besides, students are major to involve in this study and average income for the majority is RM 2001 to RM 5000. Lastly, most respondents are original from the central region which are Selangor, Kuala Lumpur and Negeri Sembilan.

Multiple Regression Analysis for the Local F\&B franchise

Table 3. Model Summary

\begin{tabular}{ccccc}
\hline Model & $\mathbf{R}$ & R Square & $\begin{array}{c}\text { Adjusted R } \\
\text { Square }\end{array}$ & $\begin{array}{c}\text { Std. Error of the } \\
\text { Estimate }\end{array}$ \\
\hline 1 & 0.806 & 0.649 & 0.646 & 0.472 \\
\hline
\end{tabular}

a. Predictors: (Constant), Brand Influence, Product Quality, Service Quality

Dependent variable: Customer Preference

Table 4. Regression Coefficients

\begin{tabular}{|c|c|c|c|c|c|}
\hline \multirow[t]{2}{*}{ Coefficients } & \multicolumn{2}{|c|}{ Unstandardized Coeffcients } & \multirow{2}{*}{$\begin{array}{c}\text { Standitized } \\
\text { Coefficients } \\
\text { Beta }\end{array}$} & \multirow[t]{2}{*}{$\mathrm{T}$} & \multirow[t]{2}{*}{ Sig. } \\
\hline & B & Std. Error & & & \\
\hline Constant & 0.772 & 0.110 & & 6.576 & 0.000 \\
\hline Brand & 0.415 & 0.054 & 0.448 & 7.757 & 0.000 \\
\hline Influence & & & & & \\
\hline $\begin{array}{l}\text { Product } \\
\text { Quality }\end{array}$ & 0.299 & 0.051 & 0.325 & 5.857 & 0.000 \\
\hline $\begin{array}{l}\text { Service } \\
\text { Quality }\end{array}$ & 0.174 & 0.047 & 0.083 & 1.568 & 0.002 \\
\hline
\end{tabular}

Dependent variable: Customer Preference

Independent variable: Brand Influence, Product Quality, Service Quality

The $\mathrm{R}$ square value is 0.649 which indicated $64.9 \%$ of the variation in customer preference towards local F\&B franchise can be explained by brand influence, product quality, and service quality. The adjusted R-square is $64.6 \%$.

The $p$-value for all independent variables is less than 0.05 which indicated that at least of all variables, is significant to customer preference towards local F\&B franchise in this study. 
INTERNATIONAL JOURNAL OF ACADEMIC RESEARCH IN BUSINESS AND SOCIAL SCIENCES Vol. 8, No. 6, June 2018, E-ISSN: 2222-6990 @ 2018 HRMARS

The equation for this model study is

Customer Preference= $0.722+0.415$ (Brand Influence) +0.299 (Product Quality) +0.174 (Service Quality)

Based on the equation, every one unit increase in brand influence, customer preference towards local F\&B franchise will increase by 0.415 , provided product quality and service quality remain unchanged. Correspondingly, every one unit increase in product quality, customer preference towards local F\&B franchise will increase by 0.299 , provided brand influence and service quality remain unchanged. Moreover, every one unit increase in service quality, customer preference towards local F\&B franchise will increase by 0.174 , provided brand influence and product quality remains unchanged. In result, brand influence is the most influential factors based on this model since the highest Beta value compares to others variables.

Multiple Regression Analysis for International F\&B franchise

Table 5. Model Summary

\begin{tabular}{ccccc}
\hline Model & R & R Square & $\begin{array}{c}\text { Adjusted R } \\
\text { Square }\end{array}$ & $\begin{array}{c}\text { Std. Error of the } \\
\text { Estimate }\end{array}$ \\
\hline 1 & 0.799 & 0.638 & 0.635 & 0.508 \\
\hline
\end{tabular}

a. Predictors: (Constant), Brand Influence, Product Quality, Service Quality

Dependent variable: Customer Preference

Table 6. Regression Coefficients

\begin{tabular}{|c|c|c|c|c|c|}
\hline \multirow{2}{*}{ Coefficients } & \multicolumn{2}{|c|}{ Unstandardized Coefficients } & \multirow{2}{*}{$\begin{array}{c}\text { Standardized } \\
\text { Coefficients } \\
\text { Beta } \\
\end{array}$} & \multirow[t]{2}{*}{$T$} & \multirow[t]{2}{*}{ Sig. } \\
\hline & B & Std. Error & & & \\
\hline Constant & 0.739 & 0.115 & & 6.402 & 0.000 \\
\hline Brand Influence & 0.441 & 0.060 & 0.487 & 7.324 & 0.000 \\
\hline Product Quality & 0.284 & 0.061 & 0.304 & 4.685 & 0.000 \\
\hline Service Quality & 0.138 & 0.053 & 0.040 & 0.704 & 0.001 \\
\hline
\end{tabular}

Dependent variable: Customer Preference

Independent variable: Brand Influence, Product Quality, Service Quality

The $R$ square value is 0.638 which indicated $63.8 \%$ of the variation in customer preference towards international F\&B franchise can be explained by brand influence, product quality, and service quality. The adjusted R-square is $63.5 \%$.

The $p$-value for all independent variables is less than 0.05 which indicated that at least of all variables, is significant to customer preference towards international F\&B franchise in this study.

The equation for this model study is

Customer Preference $=0.739+0.441$ (Brand Influence) +0.284 (Product Quality) +0.138 (Service Quality)

Based on the equation, every one unit increase in brand influence, customer preference towards international F\&B franchise will increase by 0.441 , provided product quality and service quality remain unchanged. Correspondingly, every one unit increase in product quality, customer preference towards international F\&B franchise will increase by 0.284 , provided brand influence and service quality remain unchanged. Moreover, every one unit increase in service quality, customer preference towards international F\&B franchise will increase by 0.138 , provided brand influence and product quality remains unchanged. In result, brand influence is the most influential factors based on this model since the highest Beta value compares to others variables. 
INTERNATIONAL JOURNAL OF ACADEMIC RESEARCH IN BUSINESS AND SOCIAL SCIENCES Vol. 8, No. 6, June 2018, E-ISSN: 2222-6990 @ 2018 HRMARS

Paired Sample t-Test

Table 7. Paired Sample Statistics

\begin{tabular}{lcccc}
\hline & MEAN & N & Std Deviation & Std. Error Mean \\
\hline $\begin{array}{l}\text { Pair 1 } \\
\text { Customer Preference (Local) }\end{array}$ & 3.5069 & 384 & 0.7932 & 0.04048 \\
$\begin{array}{l}\text { Customer Preference } \\
\text { (International) }\end{array}$ & 3.5143 & 384 & 0.8411 & 0.04292 \\
Pair 2 & & & & \\
Brand Influence (Local) & 3.3999 & 384 & 0.8570 & 0.04373 \\
Brand Influence & 3.5335 & 384 & 0.9302 & 0.04747 \\
(International) & & & & \\
Pair 3 & & & & \\
$\begin{array}{l}\text { Product Quality (Local) } \\
\text { Product Quality }\end{array}$ & 3.7531 & 384 & 0.8603 & 0.04390 \\
(International) & 3.8286 & 384 & 0.9005 & 0.04596 \\
Pair 4 & & & & \\
Service Quality (Local) & 3.3646 & 384 & 0.8847 & 0.04515 \\
Service Quality & 3.4991 & 384 & 0.8943 & 0.04563 \\
(International) & & & & \\
\hline
\end{tabular}

Table 8. Paired Sample t-Test

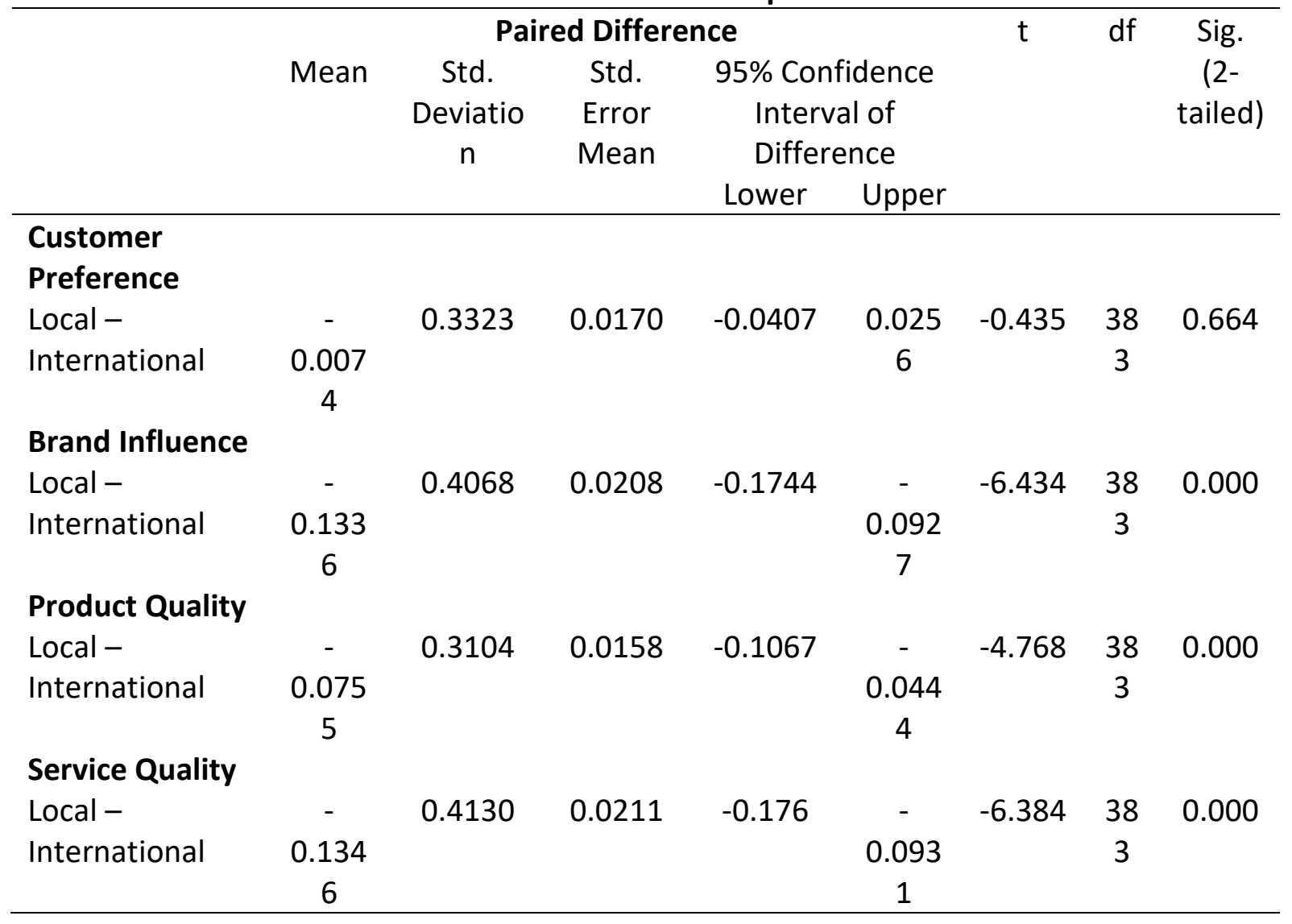


INTERNATIONAL JOURNAL OF ACADEMIC RESEARCH IN BUSINESS AND SOCIAL SCIENCES Vol. 8, No. 6, June 2018, E-ISSN: 2222-6990 @ 2018 HRMARS

Table 7 and Table 8 showed the paired sample statistic and paired sample t-test for all variables in this study towards local and international F\&B franchise. Based on both tables above, customer preference was not significance towards local and international F\&B franchise since the $p$ value is 0.664 which more than 0.01 . However, brand influence, product quality, and service quality are three factors which significant towards local and international $F \& B$ franchise since the $p$-value is 0.000 . In result, brand influence, product quality, and service quality are three variables that have a significant relationship either in local and international F\&B franchise.

\section{Discussion and Managerial Implication}

The first objective is to identify the most influential factors for customer preference towards local and international food and beverage in Malaysia. Based on multiple regression analysis, the researchers surprise that customer preference towards local and international food and beverage in Malaysia are mostly influenced by brand compare to product quality and service quality. Therefore, the researchers justify that customers prefer to buy the products especially $F \& B$ that have a great reputation in brand name either in local or international $F \& B$ franchise. This can be supported by the review from Puccinelli, Goodstein, Grewal, Price, Raghubir and Steward (2009) stated that customers tend to be influenced by-products brand name when doing purchasing process.

The second objectives are to compare the factors influence customer preference towards local and international food and beverage in Malaysia. Based on the result from paired sample t-test, it can be supported all the hypothesis in this study which indicated that brand influence, product quality, and service quality have a significant relationship with customer preference towards local and international food and beverage in Malaysia. Besides, this results showed that three factors are similar to influence customer preference both in local and international F\&B in Malaysia.

For brand influence, the researchers justify by providing the great example for the local $F \& B$ franchise which is Secret Recipe and the international F\&B franchise which is Starbucks. Both F\&B franchise has great name reputation among Malaysian which indicated that the brand name can influence customer preference. This can be supported by the study from Puccinelli et al. (2009)) stated that customers tend to be influenced by-products brand name when doing purchasing process.

Despite for product quality, the researchers justify those aesthetics especially taste is important for F\&B products. This can be explained that product quality for F\&B products are vital for local and international F\&B franchise in Malaysia. Therefore, this can be supported by the finding from Jahanshahi et al. (2011) and Suchánek et al. (2014) found out that high product quality capable to increase customer preference towards local and international F\&B franchise.

Lastly, the researchers justify that service quality is similar and influence local and international $F \& B$ franchise due to service quality can be a motivator to make customers enjoy their meal both in local and international F\&B franchise. This can be supported by the review from Sureshchandar, Rajendran, and Anantharaman (2002) stated that service quality is important for every industry due to customers satisfaction can be achieved through the services provided by the company for customers.

There are several limitations in this study. Therefore, the researchers recommended that future research to include moderator and mediator variables in the study. The mediator such as satisfaction might affect the customer preference by interpreting the relationship between within the individual variables and the dependent variable. Besides, respondents' characteristics can be influential factors towards the direct relationship between variables examined. Moreover, others 
INTERNATIONAL JOURNAL OF ACADEMIC RESEARCH IN BUSINESS AND SOCIAL SCIENCES

Vol. 8, No. 6, June 2018, E-ISSN: 2222-6990 @ 2018 HRMARS

variables such as price, and environmental factors can be identified towards customer preference for local and international F\&B franchise in Malaysia for future study as well.

In nutshell, brand influence, product quality, and service quality are three important factors to influence customer preference towards local and international F\&B franchise in Malaysia. This indicated that $F \& B$ franchisee either from local or international that ran a business in Malaysia need to pay attention for these three factors. Moreover, brand influence is the most influential factors based on the finding of study eboth for local and international F\&B franchise in Malaysia. This explained that brand name reputation is important for sustain market share in $F \& B$ industry in Malaysia.

\section{Acknowledgement}

First of all, we would like to thank God as finally we were able to complete our research. This task had been done with all efforts by group members. Besides that, we would like to take this opportunity to express my deep and sincere gratitude to our supervisor, Pn. Yuhanis binti Mohamed Noor for her kind encouragement and time while this research was in process. She had given us appropriate example and knowledge to help us understand more about this research. She inspired us greatly to work in this research. Her willingness to motivate us contributed tremendously to our research. She also makes sure we understand everything she told and explanation before we begin to work on this research.

Last but not least, we also want to thank our beloved friend whether directly or indirectly that always stick together and work hard to produce a good quality research with all afford and responsibility. Hope that all effort will give a lot of benefits to us and our group project. In addition, we also want thanks to other group which willing to share their information about this research. They always give us an ideas and comments on our project so that we can improve our project in manner. Thank you.

\section{Corresponding Author}

Lu Man Hong, Faculty of Entrepreneurship and Business, Universiti Malaysia Kelantan, Malaysia.

Email: vicklumanhong@gmail.com

\section{References}

An, M., \& Noh, Y. (2009). Airline customer satisfaction and loyalty: impact of in-flight service quality. Service Business, 3(3), 293-307.

Bhargava, S., \& Pareek, A. (2013). Service quality and its effect on customer satisfaction in unorganized retailing. International Journal of Research in Management and Social Science, 1(1), 89-98.

Buntak, K., Adelsberger, Z., \& Nađ, I. (2012). Impact of product quality on the business of the organization. International journal for quality research, 6(3), 657-672.

Chinomona, R., Mahlangu, D., \& Pooe, D. (2013). Brand service quality, satisfaction, trust and preference as predictors of consumer brand loyalty in the retailing industry. Mediterranean Journal of Social Sciences, 4(14), 181-190.

de Rezende, D. C., \& de Avelar, A. E. S. (2012). Factors that influence the consumption of food outside the home in Brazil. International journal of consumer studies, 36(3), 300-306.

Demirgünes, B. K. (2014). The antecedents of store image and customer satisfaction. International Journal of Research in Business and Social Science, 3(3), 48-62. 
INTERNATIONAL JOURNAL OF ACADEMIC RESEARCH IN BUSINESS AND SOCIAL SCIENCES

Vol. 8, No. 6, June 2018, E-ISSN: 2222-6990 @ 2018 HRMARS

Dib, H., \& Alhaddad, A. (2014). The hierarchical relationship between brand equity dimensions. European Scientific Journal, ESJ, 10(28), 183-194.

Fife-Schaw, C., Kelay, T., Vloerbergh, I., Chenoweth, J., Morrison, G., \& Lundéhn, C. (2007). Measuring customer preferences for drinking water services : An overview. Journal Techneauwa, 6, 1-48.

Habib, F. Q., Abu Dardak, R., \& Zakaria, S. (2011). Consumers' preference and consumption towards fast food: Evidences from Malaysia. Business \& Management Quaterly Review, 2(1), 14-27.

Hair, Hult, G. T. M., Ringle, C., \& Sarstedt, M. (2016). A primer on partial least squares structural equation modeling (PLS-SEM): Sage Publications.

Iyer, G., \& Kuksov, D. (2012). Competition in consumer shopping experience. Marketing Science, 31(6), 913-933.

Jahanshahi, A. A., Gashti, M. A. H., Mirdamadi, S. A., Nawaser, K., \& Khaksar, S. M. S. (2011). Study the effects of customer service and product quality on customer satisfaction and loyalty. International Journal of Humanities and Social Science, 1(7), 253-260.

Javalgi, R. G., Radulovich, L. P., Pendleton, G., \& Scherer, R. F. (2005). Sustainable competitive advantage of internet firms: A strategic framework and implications for global marketers. International Marketing Review, 22(6), 658-672.

Kamaruddin, R., \& Jusoff, K. (2009). An ARDL approach in food and beverages industry growth process in Malaysia. International Business Research, 2(3), 98-107.

Malki, Z. (2015). Twitter as a social network in academic environments for exchanging information Taibah University: A case study. International Journal of Information Technology and Computer Science, 7(10), 15-22.

Puccinelli, N. M., Goodstein, R. C., Grewal, D., Price, R., Raghubir, P., \& Stewart, D. (2009). Customer experience management in retailing: understanding the buying process. Journal of retailing, 85(1), 15-30.

Richardson, J., \& Aguiar, L. K. (2003). Consumer change in fast food preference. British Food Journal, 11(3), 77-85.

Ryan, C., Ghazali, H., \& Mohsin, A. (2011). Determinants of intention to leave a non-managerial job in the fast-food industry of West Malaysia. International Journal of Contemporary Hospitality Management, 23(3), 344-360.

Sowunmi, F., Omigie, C., \& Daniel, D. (2014). Consumers' perception on Ofada Rice in Ibadan North Local Government Area of Oyo State, Nigeria. J. Econ. Sustainab. Dev, 5, 78-85.

Suchánek, P., Richter, J., \& Králová, M. (2014). Customer satisfaction, product quality and performance of companies. Review of economic perspectives, 14(4), 329-344.

Sureshchandar, G., Rajendran, C., \& Anantharaman, R. (2002). Determinants of customer-perceived service quality: a confirmatory factor analysis approach. Journal of Services Marketing, 16(1), 9-34.

Wahid, N. A., \& Ahmed, M. (2011). The effect of attitude toward advertisement on Yemeni female consumers' attitude toward brand and purchase intention. Global Business and Management Research, 3(1), 21-29.

Zhang, Y. (2015). The impact of brand image on consumer behavior: a literature review. Open journal of business and management, 3(1), 58-62. 